\title{
Social representations of needlestick injuries
}

\author{
Juliana Almeida Marques Lubenow ${ }^{1}$ \\ Maria Eliete Batista Moura² \\ Benevina Maria Vilar Teixeira Nunes ${ }^{2}$ \\ Maria do Livramento Fortes Figueiredo ${ }^{2}$ \\ Luís Carlos Sales ${ }^{3}$
}

Objectives: understand the Social Representations about needlestick injuries elaborated by Nursing Technicians and analyze how these representations influence their conducts. Method: the data, obtained by interviews, were processed using ALCESTE software and their analysis was based on Serge Moscovici's Social Representations Theory. Results: it was evidenced that, after the accident, these professionals take care of the affected area. Then, they report the accident, motivated by the fear of catching HIV and hepatitis. The different feelings experienced are due to this fear and the way they were forwarded by the institution, reflecting in the cause they attribute to their accident. Conclusions: it was verified that knowledge about the accident as a whole is very incipient in this professional group, demanding continuing education and greater emphasis on this subject in professional training. It is expected that this study draws public authorities and health institutions' attention to the problem and that it modifies Nursing Technicians' Social Representations about percutaneous exposure.

Descriptors: Occupational Exposure; Occupational Risks; Occupational Health Nursing.

\footnotetext{
${ }^{1}$ RN, MSc., Temporary Professor, Universidade Federal da Paraíba, Brazil.

2 PhD, Adjunct Professor, Universidade Federal do Piauí, Brazil.

${ }^{3} \mathrm{PhD}$, Associate Professor, Universidade Federal do Piauí, Brazil.
} 


\section{Representações sociais dos acidentes com materiais perfurocortantes}

Objetivos: compreender as representações sociais dos acidentes com materiais perfurocortantes, elaboradas por técnicos de enfermagem, bem como analisar de que modo essas representações influenciam as condutas desses profissionais. Método: os dados, obtidos por meio de entrevistas, foram processados pelo software Alceste e a análise dos mesmos foi baseada na Teoria das Representações Sociais de Serge Moscovici. Resultados: evidenciouse que, após se acidentarem, os técnicos de enfermagem cuidam da área afetada. Em seguida, notificam o acidente, motivados pelo medo de contraírem HIV e hepatite. Os diversos sentimentos vivenciados são decorrentes desse medo e da forma como foram encaminhados pela instituição, refletindo na causa que eles atribuem ao seu acidente. Conclusões: constatouse que há conhecimento bastante incipiente por parte dessa classe profissional sobre o acidente, como um todo, havendo necessidade de educação continuada e maior ênfase quanto a esse assunto, durante a formação profissional. Espera-se que este estudo chame a atenção dos órgãos governamentais e instituições de saúde sobre o problema e modifique as representações sociais da exposição percutânea dos técnicos de enfermagem.

Descritores: Exposição Ocupacional; Riscos Ocupacionais; Enfermagem do Trabalho.

\section{Representaciones Sociales de los accidentes con materiales corto- punzantes}

Objetivos: Comprender las Representaciones Sociales de los accidentes con materiales corto-punzantes, elaboradas por Técnicos de Enfermería, así como analizar de que modo esas representaciones influencian las conductas de eses profesionales. Método: Los datos, logrados por medio de entrevistas, fueron procesados por el software ALCESTE y el análisis de los mismos fue basado en la Teoría de las Representaciones Sociales de Serge Moscovici. Resultados: se evidenció que, después de accidentarse, los Técnicos de Enfermería cuidan del área afectada. Enseguida, notifican el accidente, motivados por el miedo de que contraigan HIV y hepatitis. Los diversos sentimientos vividos son consecuentes de ese miedo y de la manera como fueron encaminados por la institución, reflejando en la causa que ellos atribuyen a su accidente. Conclusiones: se constató que hay un conocimiento bastante incipiente por parte de esa clase profesional sobre el accidente como un todo, habiendo necesidad de una educación continuada y mayor énfasis en cuanto a ese asunto durante la formación profesional. Se espera que ese estudio llame la atención de los órganos gubernamentales e instituciones de salud sobre el problema y modifique las Representaciones Sociales de la exposición percutánea de los Técnicos de Enfermería.

Descriptores: Exposición Profesional; Riesgos Laborales; Enfermería del Trabajo.

\section{Introduction}

Needlestick injuries are still frequent among health professionals, representing one of the most serious occupational accidents. Nursing Technicians and Auxiliary Nurses are more affected due to their permanent contact with patients. Risks for these accidents are related to the work process, infrastructure, available resources and care-specific characteristics ${ }^{(1)}$. Most cases of exposure to piercing and cutting material take place at hospital institutions, because that is where people with all kinds of infectious diseases meet and numerous procedures that expose health professionals to many risks are done(2).
Despite affirming that they know about safety measures, usage levels among professionals are low. Factors like the need for rapid procedures, physical and mental exhaustion and lack of Personal Protective Equipment (PPE) increase the chances of accidents(3). But not only health professionals have the responsibility to avoid accidents. Work institutions also need to get involved in the accident prevention and reduction process ${ }^{(4)}$.Thus, this research is necessary due to the severity of the diseases health professionals are exposed to, treatment expenditures for the public health 
system, several damages caused to these workers and the lack of systematic data about these accidents. The objectives of this study are to present and describe Social Representations (SR) of needlestick injuries elaborated by Nursing Technicians and to understand and analyze how these representations influence their conducts and feelings.

Social Representations Theory (SRT) was developed by Serge Moscovici in the 1950's. It is a form of knowledge that is socially elaborated and shared, within a practical and participative view, in the construction of a common reality for a social group ${ }^{(5)}$. Based on the hypothesis that subjects' behavior is oriented by their relationship with the world and the others, the SRT was used to try to understand how this relationship works and also to understand the cognitive and affective processes related to needlestick injuries.

\section{Method}

A descriptive and exploratory research was carried out at a private medium-sized hospital located in the State of Piauí, Brazil. Subjects were 16 Nursing Technicians with occupational accident records who worked in many areas of the hospital. They were selected through the occupational accidents record of the Occupational Safety Department between March and June 2011. Inclusion criteria were: victims of needlestick injuries; working at the hospital at the time of the interview; and accepting to participate in the research in writing. The Nurse-Manager of the hospital provided information about the selected professionals' place of work and work schedule. These Nursing Technicians were contacted personally and individually, the research was explained to each of them and the place and time were arranged. The interviews started after obtaining approval from the health institution and the Ethics and Research Committee at Universidade Federal do Piauí (CAAE: 0303.0.045.000-10) and participants' informed consent.

For data collection, a semi-structured interview script was used, including information like gender, age, work experience and unit where he or she was working; as well as guiding questions related to the way the accident occurred, the procedures the professional followed, preventive orientations had been provided about that kind of accident, feelings about the accident, knowledge about what to do after the exposure and possible accident causes. The data were recorded at a private room in the hospital, using an MP3 device. For the identification of each interviewee's subject, letters and numbers were used during data transcription, for example: "E1", "E2", and so on. Then, the data were processed and analyzed using ALCESTE software (Analyse Lexicale par Contexte d'un Ensemble de Segments de Texte), after being prepared according to the rules of this software(6).

\section{Results}

Altogether, 16 Nursing Technicians were interviewed: 15 women and one man; five of them were between 20 and 30 years old, six were between 30 and 40 years old and five professionals were more than 40 years of age. Seven Nursing Technicians had up to five years of work experience, six between 6 six and ten years and three of them more than ten years. Twelve professionals were working in wards at the moment of the accident, two at the operating room, one at the intensive care unit and one at the interventional laboratory.

The software processed the group of 16 interviews (corpus). The corpus of this study consisted of 16 Initial Context Units (ICU). Each ICU is an interview. Then, the program divided these ICU in 155 Elementary Context Units (ECU). Elementary Context Units are segments of three line texts, dimensioned by this software in accordance with the corpus size. ALCESTE analyzes the words in each ECU and, using the Chi-square test $\left(\chi^{2}\right)$ and the Descendant Hierarchy Classification method, it distributes them in classes. Each class is a group of ECU with a similar vocabulary. This vocabulary is formed by words that are selected according to the highest $\chi^{2}$ values and frequency. After carefully reading all ECU and the words contained in each class, the authors named the classes ${ }^{(6)}$. These classes are also associated with the study variables (age, gender, work experience and unit) (Figure 1).

Observing the dendogram, it can be noted that ALCESTE divided the classes in two large groups: one group was divided in two (class 2 and 3 ) and the other one was divided in two other groups, which were divided in four (classes 1, 6, 4 and 5). Thus, classes 2 and 3 have common meanings that differ from the other classes. At the same time, they have different ideas, which justify their separation in distinct classes. The other two groups (classes 1, 6 and classes 4, 5) also have similar meanings, but they were divided in separate classes because they talk about unlike subjects. 


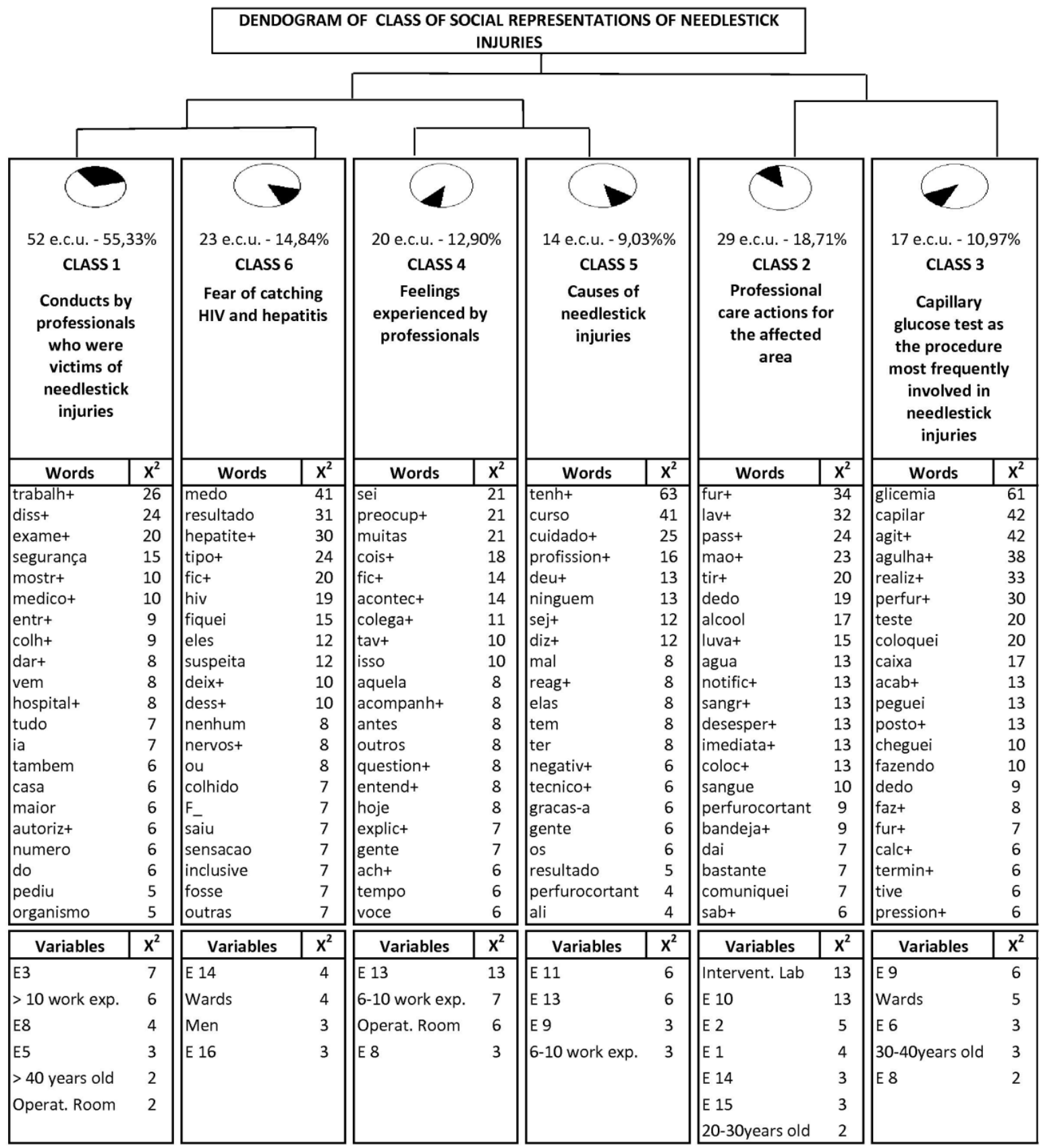

Source: ALCESTE, 2011

Figure 1 - Thematic structure of Social Representations of needlestick injuries

\section{Discussion}

The classes of Social Representations of needlestick injuries were discussed according to Serge Moscovici's theory and existing literature about these accidents and will be presented next.

\section{Class 1 - Conducts by professionals who were victims of needlestick injuries}

Class 1 consists of 52 ECU and concentrates $55.23 \%$ of ECU in the corpus. This class represents the most significant thematic context. The ECU were predominantly extracted from participants "E3", "E5" and "E8" who were over 40 years of age, with more than ten years of professional experience, and who were working at the operating room when the accident took place (Figure 1). The most prevalent words showed the employees' SR about how they proceed after the accident, revealing how the institution deals with this type of biological exposure. After reporting the event to the Nurse on duty or to the hospital's Human Resource Department, the professional contacts the Occupational 
Safety service, which forwards him/her for the necessary tests. A physician evaluates the test results and verifies the need to start chemoprophylaxis and take further tests. In this class, however, the professional the Nursing Technicians most frequently contact after the accident is the Nurse, who also contributes to mitigate the victim's despair and anxiety. This can be verified in the following ECU:

[...] the Nurse said: calm down, relax and drink the water. And then she kept talking to me, trying to prepare me psychologically to cope with negative things. Until then I was about to cry $[\ldots](\mathrm{E} 12)$.

Therefore, Nurses need thorough knowledge on the institution and the Health Ministry protocol on how to proceed with employees who were victims of needlestick injuries. As accidents are a matter of medical emergency, this employee needs prompt evaluation(7). It is verified in this study that the interviewed technicians generally knew that they should report the occurrence with a view to triggering the necessary procedures, but it is not clear whether they were aware of the urgency of this report, according to the ECU below:

I was done with my shift. I went to talk to the Nurse, she had already gone. It was Friday. I went home. [...] I did not even know what to do; I called here on Monday morning, they informed me the Nurse was not on duty in the afternoon. When I got here in the afternoon, I practically did not know what to do. I said to my colleague I could not stand working nor going to work. She told me to call HR and talk to S. [...]. Then, he told me to talk to Dr. L. She scheduled it and my material was collected (E8).

In case chemoprophylaxis is needed, this should be initiated rapidly - within two hours for HIV, and within one week for hepatitis B, despite higher effectiveness rates if administered in the first 48 hours $^{(8)}$. The Social Representations Nursing Technicians elaborated about this theme are related to the procedures that are taken after de the accident. It could be evidenced that knowledge about these accidents is based on reporting them to the service head and on collecting blood tests to identify any infections. The information these professionals have about the needlestick injuries is superficial, anchored in socially shared beliefs. SR reasoning is not aimed at proving this knowledge, but only reproducing what was assimilated ${ }^{(9)}$. The institution transmits safety to its employee when care is delivered promptly, through the implementation of its protocol of conduct in this situation.

\section{Class 6 - Fear of catching HIV and hepatitis}

Class 6 includes 23 UCEs and concentrates 14.84\% of ECU of the corpus, mainly extracted mainly from participants "E14" and "E16", male, who were working in wards when the accidents happened (Figure 1). The most prevalent words show us that, after an accident, the Nurse Technicians are concerned with the result of the blood tests collected. They know the main diseases percutaneous exposure cause. The knowledge gained in their education, associated with common sense, is expressed in psychosocial manifestations like the fear of catching hepatitis B or C, or HIV, according to the following ECU:

Like, hepatitis, HIV, I always get afraid of those. Let's see if something shows up in the test. Because we get afraid, don't we? No, because, if something was left, a trace of something, it's going to be detected (E9).

The disastrous nature of these diseases justifies the affliction these professionals revealed. Along with the physical consequences, these pathologies can cause psychosocial changes in individual and family routines, interfering in sexual practices, besides the collateral effects of chemoprophylaxis medication and job loss. Aids does not only come with the social representation of an expected shorter life and death, but related fears are anchored in preconceived concepts about the disease ${ }^{(10-11)}$. Thus, the moment of awaiting the results of the blood tests seems to be very long and distressing, as verified below:

But I want to take my other test [...] It's going to be in July and I'm counting the days to take my new test to see if there's really nothing (E8).

In the above ECU, the professional's anxiety is evidenced, while she is awaiting the verdict that can change her life forever. Psychological assistance to professionals who were accident victims is fundamental and can be provided by the institution or by the Public Health System, through Counseling and Testing Centers. These centers offer emotional support to individuals before and after serologic tests ${ }^{(7)}$.

As observed, class 6 focuses on the professionals' concern with the diseases they can acquire. These workers' social representations about these diseases refer to the associated death and tragedy sentence, linked with their scientific knowledge about these pathologies and with socially acquired knowledge, through a cognitive process that involves opinions, beliefs, images, values and tradition. The knowledge about a certain object in social representations is never 
neutral, but based on sociocultural factors. Even if the result is negative, the inconveniences these accidents cause cannot be considered transitory.

\section{Class 4 - Feelings experienced by professionals}

This semantic class consists of 20 ECU, which corresponds to $12.9 \%$ of the general corpus, and were extracted mostly from the interviewers "E8" and "E13", with 6 to 10 years of professional experience who were working in the operating room when the accident happened (Figure 1). Class 4 revealed different feelings the professionals experienced when they suffered the accident, depending on how his accident took place and the professional's psychological problem-coping ability. Professionals' great concern with the accident was evidenced, at once, a lot of concern of the professionals about the accident, because it is not known if the patient involved carried any disease, as confirmed in the following ECU:

But I'm terrified! When I think I came here to get involved in an accident, I say: my God, I don't believe this happened (E8).

Part of all of these feelings after the events could at the least be mitigated when professionals know what to do and possible measures to diminish the likelihood of catching diseases in case the source patient is seropositive for any contagious disease. The professionals need to be aware of their rights after an occupational accident and know the institutional protocol for employee orientation after occupational accidents. This avoids professional frustration related to the work institution and prevents misunderstandings. Another feeling noted was the comfort of getting information from colleagues and patient records about the involved patient's health condition, as evidenced next:

I talked to the colleagues who were taking care of the patient and they told not to get worried because there was, at least, no evidence that the patient had any disease [...]. But he was a cardiac patient, I saw it on his record. There was nothing wrong $[\ldots]$ (E13).

Although the source is not $100 \%$ reliable, as there were no serology tests proving negative result for any contagious disease, the professional felt more confident. This false security does not take into account the possibility of incomplete patient records; the patient can also omit certain information when the patient history is elaborated. Another feeling demonstrated in this study was guilt. The professionals feel powerless in a situation they could have avoided, as shown next:
It was terrible! Man, it boils down to carelessness, I don't know. We get to think we are not going to get contaminated. It's always like that: you never think it's going to happen to you (E16).

Employees often underestimate the risk, especially if the patient involved is not considered part of a risk group. These social representations were also evidenced in another study, in which the authors verified that, when professionals feel more vulnerable to infection in any invasive procedure, like taking care of an HIV patient, they are more cautious with their health, more aware of what they are doing and use $\mathrm{PPE}^{(12-13)}$. In practice, it is noted that Nursing workers have the social representation that prevention is only for proven seropositive patients. However, universal precautions are designated as such because they are destined for all patients, independently of their diagnosis(14). Professionals' social representation related to their accident engenders highly pessimistic and distressing feelings as, for them, their further destiny is obscure.

\section{Class 5 - Causes of needlestick injuries}

This thematic class is the least significant and consists of $14 \mathrm{ECU}$, which corresponds to $9.03 \%$ of the total corpus, extracted predominantly from "E9", "E11" and "E13", who had six to ten years of work experience (Figure 1). The major emphasis in class 5 was on the causes the professionals attribute to the accidents from different perspectives, depending on how they happened. The reasons we attribute to facts come from social representations, our particular perception of things or the global context ${ }^{(15)}$. In general, the interviewees report that they received orientation during their professional training and at the workplace about ways to prevent needlestick injuries, as follows:

Because we get orientation in the course and here at the hospital we had talked about it. But we know we have to be careful with needlestick material [...] (E11).

It is noted in this study that it is not a lack of information that makes professionals get involved in an accident, but other factors, for instance: lack of attention, hurry, patient's agitation, colleague's negligence, which were also evidenced in another recent study ${ }^{(16)}$. The circumstances involving needlestick injuries need to be analyzed, and not only the victims. In the analysis of these accidents, the fragmentation of reality is noted, concealing certain aspects of some situations, due to the inability to see what is in front of one's eyes ${ }^{(15)}$. Instead, in the analysis, only what one wants to see is considered, distant from the critical-reflexive approach. 
Patient agitation is another accident cause, as reported next:

Because Mr. C.A. is agitated. Sometimes he was cooperative with us, sometimes he wasn't. [...] I was already done with his capillary glucose test and when I was taking out the needle from his finger, he punched me and it punctured my finger (E12).

Hardly collaborative adults and children are patients who require a special approach during invasive procedures. The professional needs to know greater attention will be needed, and certainly the presence of another colleague or a patient's family member or acquaintance to calm him/her down. Besides wearing gloves, complementary devices should be used that offer more security in these procedures. Many American health organizations have adopted an accident prevention model (hierarchy control), which involves measures like: removal of unnecessary punctured objects; use of engineering control to protect exposed needle; and, implantation of risk reduction policies. If it is not possible to implement all these strategies or if they are not $100 \%$ effective, usual prevention measures need to be adopted ${ }^{(17-18)}$. The interviewees appoint professional negligence as another cause of accidents, according to the following ECU:

I was cleaning the balcony with alcohol, and there was an uncovered insulin needle. Then I got punctured because I didn't see it [...] Irresponsibility. Someone else's lack of commitment. I'm not perfect. Nobody is. But if there were a little bit of commitment, this could be avoided (E9).

The described situation demonstrates another professional's lack of attention. Despite affirming that they are fully aware of self-prevention, many times, they do not seem to be aware of the danger that is facing them. Because they want to do their job fast, they do not concentrate on what they are doing and do not relate their action to a potential risk. Employees need help to foresee the accident, enabling them to perform the procedures more safely(19). The social representation among professionals and hospital institutions is that the worker is always guilty of the accidents. This belief results from a previously elaborated reality, anchored in conformist principles. They do not ponder over the problem; they just accept it the way it is. Representations are, therefore, prescriptive, because they determine what it has to be thought previously ${ }^{(15)}$. The reasons for the actions cannot be attributed only to individual thought process, but also to environmental influences.

\section{Class 2 - Professional care actions for the affected} area

The class 2 is composed by $29 \mathrm{ECU}$, in other words, $18,71 \%$ of the corpus that were extracted especially from "E1", "E2", "E10", "E14" and "E15" who were 20 to 30 years old and who were allocated, at the moment of the accident, in the interventional lab (figure 1). The most prevalent words indicate that, after puncturing hands or fingers with contaminated material, professionals usually wash with water and soap, as described next:

It happened with my finger. I took the glove off and immediately put my hand under the tap and I kept washing it with water and soap (E9).

Taking care of the affected area is the first measure after the exposure. Water or saline solution and soap need to be used for washing. Besides simple washing of the exposed site, the professional usually uses antiseptics in the attempt to diminish local infection, according to the following ECU:

I cleaned and washed my hands, used alcohol [...](E1).

Antiseptics solution use is neither recommended nor contraindicated. However, it is known that the antimicrobial activity of PVP-I, for example, is substantially lower in the presence of organic material like blood or secretion ${ }^{(20)}$. Another procedure the professionals performed is to squeeze the injured area to eliminate microorganisms, according to the following ECU:

Then I kept squeezing it to see if there was blood, as if, at that moment, I thought that amount of blood, God forbid, if I got contaminated, it was all going away (E12).

However, there is no evidence that this procedure reduces transmission risks. It is important to follow Health Ministry recommendations to take care of the exposed area. Applying unnecessary procedures, with no scientific proof about their efficacy, can delay the accident report, necessary test collection and the timely start of chemoprophylaxis, when necessary. Nursing Technicians usually know what to do with the injured area after the accident, but they do not demonstrate confidence about the correct procedure: some of them use alcohol, some squeeze it and some do all these things at the same time. Lack of information can be noted to guide their conduct, in order to gain confidence and avoid delays in reporting and other suitable measures in this situation, as observed next:

I acted on the spur. I went, cleaned, washed my hands, used alcohol and knew that it was necessary to report the occupational accident to the Nurse on duty [...] (E1). 
As noted, the conduct was correct but the technician acted on the spur of the moment. When we talk about health, we cannot act by intuition. Individuals' actions are conditioned by the knowledge they have about reality(15). Thus, the Nursing Technicians' SR about care for the exposed area need to be changed or remodeled, so that these actions are based on scientific principles.

\section{Class 3 - Capillary glucose test as the procedure most frequently involved in needlestick injuries}

This class comprises $17 \mathrm{ECU}$, corresponding to $10.97 \%$ of the corpus and mostly extracted from "E6", "E8" and "E9", who were 30 to 40 years old and were working in wards when the accident happened (Figure 1). The predominant words evidence that the Nursing Technicians in this study mostly get involved in accidents when they do capillary glucose tests, as follows:

I had to do a capillary glucose test in a child's heel. When I was puncturing the heel with the needle, I squeezed it to draw out blood and put it in the glucometer. I forgot the needle with its sharp end up. Then I got punctured in the other hand and, even wearing gloves, it was pierced and bled (E4).

This simple procedure is generally performed when using insulin needles. According to the interviews, the exposures happened in two ways: when the professionals puncture the patient, they put the contaminated needle in the same tray where the glucometer is; or, when the technicians puncture the patient, they puncture themselves afterwards, due to distraction or patient agitation. It is clear that these accidents could be easily avoided. Health institutions need to provide professionals with safer materials. This needle, largely used at Brazilian hospitals and also at Family Health Units, should be replaced by pens with retractile needles, whose removal does not imply direct contact with workers' hands(21). As a result of current technological advances, the use of this type of needle becomes obsolete.

\section{Conclusions}

This study differs from previous publications as it furthered a comprehensive understanding of accidents, through Nursing Technicians' discourse, what they do after the accident, the causes they attribute to their exposure and how they feel about it. The study tried to explore all the dimensions of the accident, not only the technical part, but also the cognitive and affective elements involved. It was verified that professionals in this group have very incipient knowledge about the post- exposure protocol, as they were not so sure about what to do after the accident, making them more anxious about the possible consequences and depriving them of appropriate and immediate medical treatment. They also blame themselves or colleagues for the accident, instead of also holding the hospital responsible.

The Social Representations these professionals elaborated about the accidents influence their conducts and attitudes towards their accident. After suffering the accident, especially after performing the capillary glucose test, the Nursing Technicians take certain immediate care measures. Afterwards, they perform other conducts, motivated by the fear of contracting HIV and hepatitis. The feelings experienced result from the fear of acquiring these diseases and the way they were forwarded by the institution, reflecting in the cause they attribute to their accident. Social Representations are the meaning a subject attributes to an object according to his/her beliefs, values and myths. As these representations guide practices, it is understood that, if the professionals do not learn to appreciate preventive methods to protect themselves, they will neither perform them in their routine nor demand better work conditions from employers. Therefore, the prevention training professional training centers and health institutions offer is important to modify these representations. There are Health Ministry manuals that address this subject and discuss preventive measures. All of these orientations do not seem to be put in practice though, due to a lack of dissemination or surveillance. Therefore, professional organizations and unions should take a stand on this topic in order to defend their members' rights and welfare.

In conclusion, this study shows the need for further professional knowledge construction about needlestick injuries in Nursing. This knowledge should be aimed at preventive practices and continuing education and anchored in scientific principles. Nursing Technicians should also change their SR about percutaneous exposure in order to understand that accidents can be avoided and that their causes are not merely a matter of chance.

\section{References}

1. Silva JA, Paula VS, Almeida AJ, Villar LM. Investigação de acidentes biológicos entre profissionais de saúde. Esc Anna Nery. [periódico na Internet] 2009 [acesso 10 out 2011]; 13(3):508-16. Disponível em: $\quad$ http://www.scielo.br/scielo.php?pid=S1414 $81452009000300008 \&$ script $=$ sci_arttext 
2. Chiodi MB, Marziale MHP, Mondadori RM, Robazzi MLCC. Acidentes registrados no Centro de Referência em Saúde do Trabalhador de Ribeirão Preto, São Paulo. Rev Gaúcha Enferm. [periódico na Internet] 2010 [acesso 2011 jul 10]; 31(2):211-7. Disponível em: http://www.scielo.br/scielo.php?pid=S198314472010000200002\&script $=$ sci_arttext

3. Simão SAF, Soares CRG, Souza V, Borges RAA, Cortez EA. Acidentes de trabalho com material perfurocortante envolvendo profissionais de Enfermagem de unidade de emergência hospitalar. Rev Enferm UER]. [periódico na Internet] 2010 [acesso ago 2011]; 16(3):4004. Disponível em: http://www.facenf.uerj.br/v18n3/ v18n3a11.pdf

4. Vieira M, Padilha MICS. O HIV e o trabalhador de Enfermagem frente ao acidente com material perfurocortante. Rev ESC Enferm USP. [periódico na Internet] 2008 [acesso out 2011]; 42(4):80410. Disponível em: http://www.scielo.br/scielo. php ? pid $=$ S0080 $-62342008000400026 \&$ script $=$ sci_ arttext

5. Jodelet D. Représentations Sociales: un domaine en expansion. In: Jodelet D. Les Représentations Sociales. 5th ed. Paris: PUF; 1997. p. 31-61.

6. Camargo BV. ALCESTE: um programa informático de análise quantitativa de dados textuais. In: Moreira ASP, Camargo BV, Jesuíno JC, Nóbrega SM. Perspectivas teórico-metodológicas em representações sociais. João Pessoa: Universitária UFPB; 2005.p. 511-39.

7. Ministério da Saúde (BR). Programa Nacional para a Prevenção e Controle das Hepatites Virais. Manual de Aconselhamento em Hepatites Virais. 2005. [acesso 28 jul 2011]. Disponível em: http://bvsms.saude.gov.br/ bvs/politicas/hepatites_aconselhamento.pdf

8. Ministério da Saúde (BR). Exposição a materiais biológicos. Saúde do Trabalhador. Protocolos de Complexidade Diferenciada 3. Série A. Normas e Manuais Técnicos. 2006. [acesso 2011 jul 28]. Disponível em: http://bvsms.saude.gov.br/bvs/publicacoes/protocolo_ expos_mat_biologicos.pdf

9. Nóbrega SM. Sobre a teoria das representações sociais. In: Moreira ASP, Jesuíno JC, organizadores. Representações Sociais: teoria e prática. 2ed. João Pessoa: Universitária UFPB; 2003.p. 51-75.

10. Ribeiro AS, Gabatz RIB, Neves ET, Padoin SMM. Caracterização de acidente com material perfurocortante e a percepção da equipe de enfermagem. Cogitare Enferm. [periódico na Internet] 2009 [acesso 9 out 2011]; 14(4):660-6. Disponível em:http://ojs.c3sl.ufpr.br/ ojs2/index.php/cogitare/article/download/16379/10860
11. Neves HCC, Souza ACS, Medeiros M, Munari DB, Ribeiro LCM, Tipple AFV. Segurança dos trabalhadores de enfermagem e fatores determinantes para adesão aos equipamentos de proteção individual. Rev. LatinoAm. Enfermagem. [periódico na Internet] mar/abr 2011 [acesso 31 ago 2012];19(2):[08 telas]. Disponível em:http://www.scielo.br/scielo.php?pid=S0104$11692011000200018 \&$ script $=s c i \_$arttext\&tlng $=p t$ Inglês, Português, Espanhol.

12. Sailer GC, Marziale MHP. Vivência dos trabalhadores de enfermagem frente ao uso dos anti-retrovirais após exposição ocupacional a material biológico. Texto Contexto-Enferm. [periódico na Internet] jan/mar 2007 [acesso 9 out 2011]; 16(1):55-62. Disponível em:http://www.scielo.br/scielo.php?script=sci_arttext\& pid $=$ S0104-07072007000100007

13. Souza MCMR, Freitas MIF. Representations of Primary Care Professionals about the Occupational Risk of HIV Infection. Rev. Latino-Am. Enfermagem. [periódico na Internet] jul/ago 2010 [acesso 31 ago 2012];18(4):[08 telas]. Disponível em:http://www. scielo.br/scielo.php?script $=$ sci_arttext\&pid $=$ S0104$11692010000400013 \&$ lng $=$ pt\&nrm=iso\&tlng=pt Inglês, Português, Espanhol.

14. Ministério da Saúde (BR) [Internet] Departamento de DST, Aids e Hepatites virais. [2011] [acesso 11 jul 2011]. Disponível em: http://www.aids.gov.br/pagina/ duvidas-frequentes

15. Moscovici S. Representações Sociais: investigações em Psicologia Social. 7ed. Rio de Janeiro: Vozes; 2010. $404 \mathrm{p}$.

16. Simão SAF, Souza V, Borges RAA, Soares CRG, Cortez EA. Fatores associados aos acidentes biológicos entre profissionais de Enfermagem. Cogitare Enferm. [periódico na Internet] 2010 [acesso 10 ago 2011]; 15(1):87-91. Disponível em:http://ojs.c3sl.ufpr.br/ ojs2/index.php/cogitare/article/download/17177/11312 17. CDC. Workbook for designing, implementing, and evaluating a sharps injury prevention program. 2008. [acesso 10 jul 2011]. Disponível em:http://www.cdc. gov/sharpssafety/pdf/sharpsworkbook_2008.pdf

18. American Nurses Association. American Nurses Association's Needlestick Prevention Guide. 2002. [acesso 16 ago 2011]. Disponível em: http://www.nursingworld. org/FunctionalMenuCategories/MediaResources/ MediaBackgrounders/NeedlestickPrevention.aspx

19. Vieira M, Padilha MI, Pinheiro RDC. Análise dos acidentes com material biológico em trabalhadores da saúde. Rev. Latino-Am. Enfermagem. [periódico na Internet] mar/abr 2011 [acesso 31 ago 
2012];19(2):[08 telas]. Disponível em: http://www. scielo.br/scielo.php?script=sci_arttext\&pid=S0104$11692011000200015 \& \operatorname{lng}=$ pt\&nrm=iso\&tlng=pt Inglês, Português, Espanhol.

20. World Health Organization. WHO Guidelines on Hand Hygiene in Health Care. First Global Patient Safety Challenge Clean Care is Safer care. 2009. [acesso 3 ago 2011]. Disponível em:http://whqlibdoc.who.int/ publications/2009/9789241597906_eng.pdf/

21. Cardoso ACM, Figueiredo RM. Biological Risk in Nursing Care Provided in Family Health Units. Rev. Latino-Am. Enfermagem. [periódico na Internet] mai/jun 2010 [acesso 9 ago 2011];18(3):[6 telas]. Disponível em: $\quad$ http://www.scielo.br/scielo.php?pid=S0104$11692010000300011 \&$ script=sci_arttext Inglês, Português, Espanhol. 